\title{
The Rover Task Force: A Case Study in Proactive and Reactive Policy Intervention?
}

\author{
David Bailey and Stewart MacNeill ${ }^{1}$
}

\begin{abstract}
The paper examines the policy responses in the UK West Midlands to the successive crises at the car maker MG-Rover. Whilst the firm's eventual collapse in 2005 was a substantial shock to the west Midlands economy, the impact was been much less than was anticipated when the firm was first threatened with closure in 2000 at the time of its break-up and sale by BMW. Although the firm struggled as an independent producer, the five years of continued production until 2005 and the work of the initial Rover Task Force (RTF I), enabled many suppliers to adjust and diversify away from their hitherto dependence on MG-Rover resulting in as many as 10,000-12,000 jobs being 'saved'. This first intervention was later followed by a programme to help exworkers to find new jobs or re-train and assist supply firms to continue trading in the short term. Examination of the effectiveness of these emergency initiatives enables a wider discussion about the nature of industrial policy in the region and the work of the local RDA's cluster based approach to economic development and business support. Whilst the actions taken were successful in a number of aspects there were a number of significant 'failures' at both national and local level. The MG-Rover case also illustrates a number of critical issues pertaining to regionally based cluster policies and the organisation of cluster management groups where the 'cluster' in question not only crosses both administrative and 'sector' boundaries but is also subject to the imperatives of the global market car market.
\end{abstract}

\section{Introduction}

In early 2000 when BMW announced their intention to sell and break up the UK car maker, MG-Rover, the British Government was largely caught unawares. However, with the subsequent purchase of Land Rover by Ford and BMW's retention of the Oxford (Mini production), Warwickshire (engines) and Swindon (pressings) plants, the worst of the crisis seemed to be over and the remaining need was to address the 
consequences of reduced production or possible closure of the Longbridge factory in Birmingham. Their response was to set up, in short time, the 'Rover Task Force' under the leadership of the newly formed RDA (Advantage West Midlands - AWM) and with the involvement and support of the Government Office for the West Midlands (GOWM).

For AWM the MG-Rover crisis came as an early challenge. The English RDAs ${ }^{2}$ had just been created, beginning their operations in spring 2000, (see Mawson (2000) and Benneworth (2001) for accounts) and were under Government instructions to draw up economic strategies for their regions. In the West Midlands the RDA (AWM) had set out its initial economic strategy (AWM, 1999) based on a business sector approach derived from the EC funded Regional Innovation Strategy (Oughton et al, 1996). However, during the same period the Government adopted cluster policy (DTI, 1998) and requested the RDAs to draw up new plans based on the cluster approach using the Porter model (Andriani et al, 2005). Thus, although the policy was conceived centrally (DTI, 1998, 2003; DTI/DfEE, 2001), its implementation was to be at regional level and led by the newly formed RDAs (Peck and McGuinness, 2003).

As might be expected, with the introduction of any major new governance structure, all RDAs faced a number of initial problems. These included concerns about budgets (Robson et al, 2000), autonomy and authority (Fuller et al, 2002; Webb and Collis, 2000). They also had the problem of the short timescale of just six months, allowed by central government, in which to draw up their Regional Economic Strategies (Roberts and Benneworth, 2001). Such challenges were accompanied by constraints on the resources available to English RDAs compared to the devolved agencies in Scotland and Wales exacerbating the difficulties of establishing political influence amongst the existing, and often better resourced, regional organisations (Burfitt et al 2007). For example, when AWM produced its original strategy documents, criticisms of both the content and the consultation process (Ayers et al, 2002) were so strong that a major revision was undertaken and the Chief Executive subsequently resigned.

Thus, as well as coming to terms with its newly assigned role and establishing lines of authority and delineation with other local organisations such as the Regional Assembly, the Regional Government Office, the Local Authorities and others, AWM was faced with the first Rover 'crisis' in 2000, with all its potential economic and 
political fall-out, and the challenge of developing a new policy direction based on clusters.

Cluster policy itself, as derived from Michael Porter's (1990, 1998) analysis, emerged as the archetype 'soft' intervention measure in the 1990s and early 2000s. However, a number of critical questions emerged about its theoretical underpinnings (Martin and Sunley, 2003) and modes of implementation (Anderssen et al, 2004) including the difficulties of defining geographical or sectoral cluster boundaries or addressing institutional rivalries within cluster support organisations (Enright, 2001). As a result, the value of the cluster approach as an economic development tool is now questioned in some policy and academic quarters (Peck and McGuinness, 2003; Tully and Berkeley, 2004; Sadler, 2004) or is even seen as somewhat passé against scenarios where future economic development is dependent upon cross-sectoral innovation and 'platform technologies' (Asheim et al, 2006).

However, in its favour there are features, such as the focus on selected networks and the concentration on innovation (Raines, 2002) that had the potential, for AWM, and the West Midlands, to develop new initiatives to help address the over-reliance on the automotive industry and on Rover in particular. In the event, after much discussion, AWM identified 10 target clusters (AWM, 2001) with 'automotive' included as one of 5 described as 'established' (transport technologies, building technologies, food and drink, tourism and leisure and high value consumer products), together with 7 others categorised as either 'growing' (ICT, specialist business and professional services) or 'aspirational' (interactive media and medical technologies).

In summary, the RDA was faced with addressing a crisis in the short term while creating structures and mechanisms to implement cluster policy which was untried in the UK and about which it had only limited understanding (Burfitt et al, 2007) and with limited budgets. Not surprisingly it fell back on existing structures and funding arrangements and tried, with limited success, to meld these into its overall cluster plan. In this account of the implementation of the 'Rover package' we trace the actions taken and their success, or otherwise, against the background of global pressures, the on-going changes in the West Midlands automotive industry and the policy debate. In doing so, we examine the difficulties of applying cluster policy to a 
global industry, its ability to deal with shocks requiring immediate action, and the RDA's attempts to integrate the cluster concept with more traditional business support and area regeneration measures .

\section{The Rover Task Force Mark 1 (RTF1)}

With the purchase of the Longbridge plant by the Phoenix ${ }^{3}$ consortium, the Government saw a settlement that, despite its inherent weaknesses, was politically popular and satisfied the Trade Unions. In consequence it saw the Rover issue as 'closed' and felt that no further action was necessary. However, the GOWM, in private discussions with Stephen Byers (then Secretary of State at the DTI), pressed, and won the argument, for a package of measures to support businesses most dependent on MG-Rover custom and, at the same time, address long-term weaknesses in the in the regional economy. ${ }^{4}$ Thus the Rover Task Force Report (RTF, 2000) focused on the inter-linked themes of modernisation (with funding of $£ 17$ million), diversification ( $£ 19.7$ million) and regeneration ( $£ 22$ million). A further action was to extend the existing Accelerate Programme of supply chain improvement outside the confines of the then Objective 2 area to offer support nationally to companies in the Rover supply base (see Accelerate, 2002).

In fact Accelerate had been in existence since 1996 with the objective of providing individual companies with small grants to support process improvement (so-called 'lean manufacturing') at shop floor level. However, whilst Accelerate was given extra resources, the RTF also recognised that over-reliance on the automotive sector, and MG-Rover in particular, plus the concentration in low value-added 'metal bashing', and a lack of a significant involvement in higher value-added areas as electronics, communications or fuel saving technologies, meant the region was particularly vulnerable given the global changes taking place. Thus while Modernisation included a number of linked initiatives to improve competitiveness, through increased productivity, the new Diversification programme sought to help suppliers diversify away from Rover, and from automotive in general, by encouraging the application of engineering skills to other industries such as medical and nano technologies. Delivery of all these initiatives was through a combination of existing organisations including Accelerate, based at Birmingham Chamber of Commerce, and the Small Business Service operating through the network of Business Links. 
Thus the support actions arising out of the first Rover Task Force were, for the most part, not based upon the cluster concepts of networks but on 'old fashioned' industrial policy. Grants were available at the level of individual companies, which although having some involvement with the sector, were often best described as 'manufacturing', rather than automotive, since in many cases they also supplied other industries. (MacNeill, et al, 2001)

Given the on-going concern about Rover's long term prospects, RTF1 also initiated spatial targeting via corridors of regeneration. The RTF1 Final Report identified three areas for in-depth study of their growth potential as "high-tech corridors": the Central Technology Belt (CTB) running along the main A38 trunk road running from the centre of Birmingham to Malvern passing the University of Birmingham and the University Trust hospitals, the (down-scaled) Longbridge plant and ending in rural Worcestershire at the Malvern Science Park and the site of the high tech company Qinetiq ${ }^{5}$. Amongst the possibilities identified in the RTF report were developments related to the University of Birmingham, such as a new Medipark (RTF, 2000; Burfitt and Ferrari, 2008). Other suggested "corridors" were the Coventry/Solihull/Warwick (CSW) area and the Wolverhampton/Telford Technology Corridor (WTTC). Linking these area based initiatives with the clusters would have provided a genuine innovation but for the most part AWM was unable to achieve this except in the regeneration of the unused areas of the Longbridge site.

\section{The West Midlands and its automotive industry}

The region has a history of automotive production dating back to the first factory of the Lanchester Motor Company in 1895. The Longbridge plant in Birmingham was set up by Herbert Austin in 1905 and grew into a major complex rivalling any in Europe. As in other automotive producing areas, the supply industry grew alongside the car makers and metal based trades, dating from the industrial revolution, were easily able to adapt to the manufacture of automotive parts. The final collapse of MGRover in 2005 thus ended 100 years of car making on the Longbridge site. When this was followed, in late 2006, by the closure of the PSA factory in Coventry volume production in the region effectively ended leaving only higher-value 'niche production' at Jaguar, Land Rover and Aston Martin ${ }^{6}$ and a number of small specialist 
manufacturers of sports cars, construction and public service vehicles. Regional production suffered further, in 2004, when Ford transferred part of Jaguar and Land Rover production to Halewood in North West England to achieve productivity gains not thought possible at West Midlands based plants with (in part) historically adversarial labour relations, and given the much larger capacity of the Halewood operation. This situation may not change with the take over of Jaguar and Land Rover by the Indian conglomerate TATA. Already there is speculation that the next generation of smaller Land Rovers may be built at the Liverpool plant.

However, despite these high profile closures, the West Midlands is still at the heart of the UK auto industry, with around $15 \%$ of car production, $28 \%$ of market value, and $28 \%$ of UK jobs in the sector (ONS, 2005). There is a large supply industry including the legacy of first tier suppliers that evolved alongside the auto makers and an extensive supply matrix of smaller companies still largely geared to the former volume production. The cluster can thus be described as 'mature' and 'undergoing change in common with other old industrial clusters' (Rosenfeld, 2002). Although the current production volume, at around $15 \%$ of the UK total, is considerably lower than the $30 \%$ a few years ago (MacNeill, 2003), the high value of the vehicles produced is reflected in the market value of production at $28 \%$ of the UK total.

\section{Collapse and Impact}

The 'final' collapse of MG-Rover in 2005, although widely predicted by industry experts, sent shock waves through the region. The firm's turnover accounted for as much as $1 \%$ of regional GDP and $£ 200$ million a year in government revenue alone was lost. The firm ceased operations owing $£ 1.4$ billion to creditors, with $£ 109$ million owed to UK-based suppliers (House of Commons, 2006), who may (eventually) see only around a penny in the pound for what they were owed. MGRover's inability to pay its suppliers, and the resulting cash flow problems in the supply chain, cut off the supply into the factory (and caused the final collapse). It also meant that it was impossible for the administrator to restart production. The pension fund deficit also ran to around $£ 500$ million, with the new Pension Protection Fund (backed by private sector money) having to make up the difference. In addition to the 6,000 workers who lost their jobs at Longbridge, the supply regional supply was forecast to be badly hit. The 'jobs multiplier' in the car industry is difficult to 
calculate, depending on the degree to which the car is made in house as opposed to assembly of bought-in components, as well as the degree to which components are sourced locally as against internationally. Given such differences, multipliers have been estimated to range from 1:1 to 1:4. However, in the case of Longbridge, the combination of in-house engine production and a shift to overseas sourcing meant a relatively low local jobs multiplier nearer to the 1:1 end of the range, implying a maximum of around 12,000-13,000 job losses in the broader economy. This 'back-ofthe-envelope' 1:1 calculation in fact quite closely matches the physical 'head-count' figure of around 12,200 made by AWM by counting suppliers and the total number of jobs dependent on MG-Rover. (See also Birmingham City Council, in Birmingham Mail, 2005). Given that a Longbridge shut-down in 2000 would have resulted in an estimated 22,500 job losses it can be suggested that the five years of additional time bought by the Phoenix ownership, combined with the efforts of AWM, had indeed enabled suppliers to diversify away from the firm, 'saving' around 10,000 jobs (House of Commons, 2006).

However, more recently it has been estimated that the number of total jobs lost directly is around 8,500 and not 12,000 (i.e. approximately 6000 at Longbridge and 2,500 in the wider supply chain) with 'only' 11 significant suppliers ceasing operations up to March 2006 (ibid). A number of relevant factors can be identified here. Firstly, the Longbridge run-down over 2000-2005 and the diversification efforts of AWM, precipitated a greater shift by component suppliers to other activities beyond MG-Rover, in excess of that initially estimated. Indeed, over this time, the number of British firms depending on MG-Rover for over $20 \%$ of their sales dropped from 161 to 74, with only 57 in the West Midlands region (ibid). Secondly, the emergency policy response in 2005 involved a package of measures including a wagesubsidy element for suppliers. This bought some much-needed extra time for firms facing extreme cash-flow problems and saved jobs. It is to this that we turn next.

\section{Rover Task Force Mark 2: Picking up the Pieces?}

Having been alerted at the beginning of 2005, AWM and the national government were able to move quickly when MG-Rover finally collapsed in April 2005. A second Rover Task Force (RTF 2) was set up with the objectives of: helping suppliers to maintain operations in the short term whilst assisting them to diversify; aiding those 
losing their jobs to find new employment; and supporting the broader community. An aid package worth $£ 176$ million was made available, including $£ 50$ million for retraining (up to level 2 skills), $£ 40$ million in redundancy payments, a $£ 24$ million loan fund to help otherwise viable businesses, and $£ 41.6$ million to support MG-Rover suppliers to sustain trading. Another $£ 7.6$ million was announced by AWM in June 2005 to assist with supplier diversification. The tailored support for suppliers proved critical in limiting the short term damage to the local economy. For example, a $£ 3.4$ million Wage Replacement Scheme helped 170 firms and kept around 3000 workers in place for the critical weeks following the collapse, with 1329 'confirmed' jobs being saved in this way (RTF II, 2006).

By February 2006, of 6300 claimants resulting from the MG-Rover collapse, 4000 were back in work, 2000 had received some form of training, and 2300 remained out of work (RTF II, 2006). Although portrayed in the media as a great success story, in enabling structural change and assisting workers back into employment, the fact that 2300 remained out of work ten months after the collapse highlights some of the broader structural problems in the local economy. As the Birmingham Post noted in its editorial comment in May 2008 (10/05/08; 9):

'Economic Strategy for the Region cannot be based on the assumption that everything will go as we hope. The Rover Task force has been widely praised for its work in supporting the local economy following the collapse of MG Rover in 2005. The work is not over. There are still far too many people in parts of Birmingham who want to work but cannot find suitable, long term positions which make the best use of the skills they have'.

\section{Recognising Policy Successes and Shortcomings}

The actions taken to address the on-going MG-Rover difficulties from 2000 to 2005 can be described as a successful example of crisis management. As outlined above, there were clear benefits in addressing the short-term market needs of local supply companies and the unemployment that resulted from the final closure of the company. In policy terms the crisis prompted an acceleration of regional-level initiatives which have undoubtedly brought benefits to the local economy. Firstly, the modernisation and diversification agendas recognised the need to shift suppliers away from dependence on MG-Rover; in so doing, they assisted firms looking for new markets and applications and contributed to the 10,000-12,000 jobs 'saved' over 2000 to 2005. 
Secondly, the MG-Rover crises kick-started a regeneration agenda and the development of spatial targeted policies to develop new technologies centred on the corridors, which in two cases, at least, have begun to draw in other key local organisations such as universities.

More broadly, the crisis highlighted the need to move the auto 'cluster' towards highperformance and prestige markets, to diversify the economic base away from dependence on the sector, as well as the need to overcome a defensive style of capitalism amongst small firms that mitigates against co-operation and the benefits of innovative activity therein (see De Propris, 2000).

However, whilst recognising these successes, the MG-Rover debacle raises a number of broad policy issues at both the national and local level and highlights the failure to 'join up' different governance levels at key points. At the local level it is clear that AWM faced a number of difficulties in dealing with the MG-Rover situation. The first 'crisis' came just after the RDA had been set up and when establishing RDAs' local political influence was problematic (House of Commons, 2004, p.20; Gough, 2003) especially given the introduction, by different Government departments, of regional centres of the better resourced Small Business Service (SBS) and the Learning and Skills Councils (LSCs). To some extent the crisis assisted AWM in this process, especially in respect of collaboration with the local LSC. Fuller et al (2002) note the lack of formal links between RDAs and the LSCs but observe that Rover was "very important in fostering joint strategy making and action across the region" (ibid).

Given these difficulties, it was inevitable that the RDA would have to turn to established groups and projects for delivery of the RTF measures. Hence, although there were some genuinely new initiatives, such as the 'technology corridors', much of the direct support to manufacturing companies was based upon the existing, and 'Rovercentric' initiative, Accelerate, which had been developed as a process-oriented supplier improvement (short-term reduction in supply costs) programme - as sought by the region's major companies and, in particular, MG-Rover itself. Thus, although the RTF funds provided valuable direct support to individual companies, little was done to address the region's on-going skills shortages (Tilson, 1997) or to improve the technological base. 
A key trend in the region, exacerbated by the recent closures, has been the shift away from mass production towards smaller-scale high value-added work. As a result manufacturing employment in Birmingham had fallen by 100,000 since the mid 1980s, and is forecast to fall by another $10 \%$ over the next 10 years (BSEDF, 2005). Although the service sector has grown rapidly in this period (and now accounts for $80 \%$ of jobs in Birmingham), these new jobs have been quite diverse ranging from high level professional services to relatively low-paid (often part-time) work in retail or wholesaling. In addition, although overall employment levels are up compared with 20 years ago, unemployment remains higher than the national average, with $5.7 \%$ of the regional workforce and $7.5 \%$ of that Birmingham unemployed at the time of writing (ONS, 2007). This is highly concentrated in pockets of deprivation, where people have been unable to cope with the structural change that has unfolded around them. A real legacy effect is the absence of a "widespread culture of studying for qualifications", with $37 \%$ of local $16-64$ years old having no recognised qualifications and 31\% no NVQ level skills in 2001 (BSEDF, 2005). This position derives from former years when the automotive sector provided mass employment and good rates of pay for largely unskilled blue collar work.

This low educational level has been a real factor in the MG-Rover case, where only $10 \%$ of employees had level 4 qualifications. This was against a background where most of the growth sectors in the local (South West Birmingham) economy are in high-quality public sector activities (e.g. higher education and medical care) requiring Level 3 or 4 or in the new growth sectors (such as aeronautics, where turnover is forecast by some to double by 2020), which creates a supply-demand mismatch as workers with lower skills leave manufacturing activities such as assembly work (Birmingham Post, 20/04/06). Cowling and Isles (2005) noted that local employers were "offering jobs for the only most highly skilled" leaving "a core of around $75 \%$ of the Longbridge labour force who are lower skilled operatives". This raised two key points for their longer-term assimilation and indeed for the development of the local economy. Firstly, there is a need for 'cross-training' initiatives. Whilst the aid package provided assistance for skills upgrading to level 2, it was clear that a greater effort is required given the requirements of the growth sectors. Secondly, it suggested a need for geographical mobility on the part of the least skilled workers coming out of Longbridge, yet blue collar mobility is often a real problem in such situations (ibid). 
Although the 'cost' of closure fell most heavily on those unable to shift into new employment, those back in work have experienced substantial losses, as a study by the Work Foundation for the BBC (Radio 4) has found, with ex-MG-Rover workers back in full-time employment earning around $£ 3500$ a year less and those in part-time $£ 10,500$ less with only those in self-employment now earning more (Armstrong, 2006; Armstrong et al 2008). Furthermore, nearly half viewed their 'new' job as worse than their MG-Rover job. Also, the loss of security means an increased likelihood of unemployment in future years, thus adding to stress levels. As Armstrong (ibid) notes, longer term policies are required to build skill levels in Birmingham and tackle growing labour market polarisation and inequality.

While it is important to protect and nurture the supply chain and thereby attempt to 'embed' global firms, regional development policy also needs to foster knowledge intensive competencies through the regional 'collective learning' which is central to the development of a successful milieu or set of territorial relationships. Camagni (1991) sees these developing tacitly through factors such as the local labour market, customer-supplier technical and organisational interchange, imitation processes, reverse engineering, exhibition of successful 'climatisation', application of general technology to local needs, 'cafeteria' effects and specialised service provision. Similarly, Keeble et al (1999) see regional collective learning as "the emergence of basic common knowledge and procedures across a set of geographically proximate firms which facilitates co-operation and solutions to problems" through establishing a common language, trust, shared technological knowledge, as well as tacit codes of conduct. This links in turn with the concepts of the 'learning region' and 'regional innovation systems'.

In this sense a regional cluster policy has the potential to take a holistic approach focused on 'soft infrastructure' and competence building (Lundequist and Power, 2002). Implemented in this way, the cluster approach has the potential to increase the regional technology base and develop ties between footloose transnational firms and the locality (see Malecki, 1997). However, by concentrating support through the Accelerate programme, rather than through the developing cluster policy, the RTF made relatively little progress in this direction. It is clear however that providing the 'soft support' associated with the learning economy represents a major challenge (see 
Storper, 1997), not least for an RDA lacking power and resources over many of the areas in question.

Although unable to mobilise forces in time to address these deeper structural issues, AWM did at least recognise the need for a broad approach. Thus during the period between the two MG-Rover crises a considerable investment in new technology was made at Warwick Manufacturing Group where more than $£ 30$ was made available by a combination of the DTI (BERR) and AWM for the PARD ${ }^{7}$ Programme. This encompassed a range of high tech projects, including advanced materials (formability of composites and alloys of aluminium and steel), joining and assembly technologies, electronics (testing rather than development) and hybrid systems, and was an attempt to both 'kick-start' new technology and to 'embed' Ford in the region. Although a review of PARD has yet to be undertaken it is apparent that it has achieved many of its short term goals. However, the longer term sustainability is in doubt without the addition of further public funding. In addition the objective of keeping Ford in the region was unrealistic given the scale of the parent company's losses. ${ }^{8}$

\section{The global paradigm of the industry}

Although the failures of the RTF to address the broader issues for the West Midlands automotive industry have become apparent, it is also fair to observe that the Agency was genuinely limited in what it could achieve. Firstly, support for a modernised West Midlands auto 'cluster', based around major assemblers and first-tier suppliers, was difficult to maintain given the industry's global shifts and oligopsonistic dominance by footloose global players headquartered elsewhere. Moreover, it needs to be recognised that, in England, the industry extends beyond a single region. Despite the retrenchment of national-level industrial policy and the shift to the regional scale, there is clearly a need for national level coordination of RDA strategies. The administrative (and aspirant political) scale of the West Midlands is inadequate for a supply system covering at least five English regions (East Midlands, North West, South East, South West and the West Midlands) with each auto 'cluster' forming part of a national or international network. Although the initial Rover Task Force (RTF1) extended eligibility to companies outside the West Midlands this was both short-term and a minor aspect of the overall package which was not renewed in subsequent years. As noted by Peck and McGuiness (2001, in Waters and Lawton Smith, 2002) 
note "the alternative involving greater collaboration between regions in developing (cluster) strategies has yet to be taken seriously".

Also, whilst MG-Rover's problems have centred on long-seated organisational and management failures, a major contributing factor was the series of national-level policy failures going back to the $1950 \mathrm{~s}^{9}$ as detailed by Holweg, and Oliver (2005) and Bailey et al (2008). This needs to be recognised for the development of future industrial policy given that the latter is now 'back on the agenda' in some sense. Central government's response to the MG-Rover affair over the five years between the crises was typically reactive, with the setting up of the RTF1 largely bolted onto other competitiveness programmes such as the Accelerate programme and RTF2 coming after MG-Rover's closure in 2005. The DTI itself only intervened in late 2004 and early 2005, when the firm was rapidly approaching its final demise.

The 2006 National Audit Office (NAO) Report into the DTI's handling of the MGRover collapse deserves close scrutiny in this respect. In the report, AWM and local actors are given high marks for their response to the crisis; helping 4000 workers back into work was indeed a major achievement, although it should be stressed that there remains much to be done for the remaining unemployed workers. ${ }^{10}$ There is also acknowledgement that the knock-on effects of the MG-Rover crash on the supply chain were not as severe as first anticipated thanks to the actions of RTF1 and AWM in working to diversify firms away from MG-Rover over the previous five years. As noted, as many as 10,000-12,000 jobs were 'saved' in this way.

Whilst the media has focused on the NAO's criticism of government actions, such as spending $£ 6.5$ million to pay the MG-Rover wage bill for 5 days to see if the Chinese vehicle maker, Shanghai Automotive Industry Corporation, could be tempted to buy the company as a going concern, a more substantial criticism of the DTI, only partly recognised by the report, is that it took so long to realise that MG-Rover was struggling and then rushed into contingency planning that focused too much on how to deal with a collapse of the firm. For example, less than a year before MG-Rover's collapse, in May 2004 the then DTI Secretary of State, Patricia Hewitt, stated that she was "very pleased with Rover's performance" and that the Phoenix four had taken "very big risks" in starting up Rover again. Yet it was clear to many that MG-Rover 
was selling off its assets (land, the parts business, its finance arm and later its IPRs) in an increasingly desperate attempt to keep going. As early as 2002/3 several commentators said that the firm had no long-term future without a partner and that it was running out of time (see Bailey 2003). Initial attempts were made, in 2003, to link to TATA. However, the cooperation floundered when the Indian built small car that was imported and badged as the 'City Rover' proved to be a market flop. The question then arises as to what the DTI was doing in the following period; was it helping MG-Rover to do strike an alternative agreement with Shanghai or another firm? A deal in 2002/3 might well have saved some small scale production and research and development at Longbridge. (Whilst the recently announced tie-up between Nanjing Automotive Corporation (NAC) and SAIC ${ }^{11}$ might offer the hope that $R \& D$ may return to Longbridge, this has yet to be confirmed.)

In reality the DTI was not geared to brokering such a deal since it did not see ongoing and detailed monitoring of strategic companies as a relevant part of modern industrial policy. This lack of intelligence gathering was a key criticism in 2000 by the House of Commons Select Committee on Trade and Industry when it examined the circumstances of the BMW sale (Bailey 2003a). The Department had failed to pick up BMW's 'ten minutes to midnight' warning and, as Bailey (Birmingham Post, 14/03/06) notes:

"the penny dropped for the DTI on the dire state of MGR only in 2004, sometime after Ms Hewitt's endorsement of the Phoenix Four. This was way too late, and in the following months the DTI was trying to play catch up when the company was fast approaching the end game".

It is clear that in those dying days little could have been done. However, taken as a whole, the NAO Report does not make as comfortable reading for the DTI as some government ministers have claimed.

In the whole saga of the protracted demise of MG-R there are important lessons to be learnt for industrial policy design and delivery. 


\section{Reconsidering Industrial Policy}

Firstly, a general point is that the strengths and importance of British industry are often underestimated by policy makers. Whilst manufacturing accounts for just onesixth of Britain's GDP (GVA), it still accounts for thee-quarters of all business R\&D and two-thirds of British exports (Hutton, 2007). Too often 'traditional' manufacturing is seen as inferior to the 'knowledge' intensive service sector. This is superficial as much of the remaining manufacturing base is very much 'knowledge intensive' and the two sectors have blurred to the point where it is difficult to disentangle one from the other. Underpinning car production itself is a wide range of research and design across many disciplines that is provided by firms classed within 'service' sectors. In addition, car-buyers also purchase a complex package of services including finance, maintenance, insurance and so on, all of which provide downstream service sector jobs - which considerably outnumber those in the upstream supply matrix (MacNeill, 2003).

To compete in high-technology and cross-sectoral activities, the UK needs investment in the knowledge base and long term strategies. As the economics journalist Will Hutton (1999) has consistently argued, investment pay-back periods are often too short and rates of return hurdles too high. Whilst this comment refers to industry itself, it is often also true of public policy and, as a result, investment per employee and in $R \& D$ remain relatively weak by international standards contributing to lower productivity levels in Britain than in the US, France and Germany. Whilst patent figures need to be interpreted with much care, DTI figures show that for $£ 10 \mathrm{~m}$ invested in $R \& D$, Britain produced only 1.8 patents against 4.4 in the US (Hussain, 2007). Adding in the skills gap identified in the Leitch Review (Leitch, 2005), some of the challenges for business and policy-makers become clearer. In spite of a major investment in skills and plans for change, Leitch concluded that Britain will only have managed to "run to stand still" by 2020, whilst international competition will have intensified further. It is therefore unsurprising that Britain has seen a more rapid rundown than any other European economy, with well over a million manufacturing job losses in the last ten years. Too much manufacturing capacity may have been lost, and the failure to develop the new, dynamic manufacturing industries of the future may create future economic problems (see Rowthorn and Coutts, 2004). This makes it 
imperative that Britain develops a more pro-active industrial policy; not one based on protectionism or 'national champions', but on fostering networks of high-tech small firms linked with innovation and ideas coming out of universities and underpinned by investment in $\mathrm{R} \& \mathrm{D}$, skills and training.

To a large extent, the strengths and weaknesses of recent policy are illustrated by the MG-Rover crisis and the policy response. As we have already observed, MG-Rover was the end result of a long string of failed policy measures. In the five years up to the collapse, the RDA, Advantage West Midlands, and the Rover Task Force proved very effective in giving short term help to suppliers. It is estimated that as many as 12, 000 jobs (and key engineering skills) were saved in the process. However, notwithstanding the diversification agenda, most of the help given to the companies themselves was along the same lines as that provided by the existing Accelerate Programme, namely direct intervention to individual firms to improve their shop floor processes. This concentration on manufacturing was a traditional policy response in the region and is consistent with the desire of companies to minimise costs and maximise profits. However, although always be important, in a high cost 'western economy', cost reduction measures, are not sufficient as the main policy tool to aid business development or even survival. Wage differentials between the UK and low cost economies in central and Eastern Europe (or further east) necessitate additional actions to support product innovation and improve the technological base. Unfortunately, however short-term extraction of rents has all too often been seen as the main priority as the dominance of such measures in publicly financed support for the automotive industry over the last ten years illustrates.

To be fair the RDA clearly recognised many of these issues. It adopted clusters as its main economic development tool, albeit with DTI 'guidance', a policy which has the potential to facilitate knowledge based networking (Steiner, 2006), amongst a range of 'up-stream' and 'downstream' players, and link together long and short term policies (Benneworth and Henry, 2004). However, at the time of the first Rover crisis the Agency was unable to harness longer term policy in parallel with the short term emergency measures. It is also fair to observe that in the initial stages it did have a sufficient understanding of the cluster concept. Its difficulties in building a cluster support organisation for the medical technology cluster have been documented by 
Burfitt et al (2007) and similar issues arose with the automotive cluster. However, unlike in the former case, where the different agendas of public sector institutions were problematic, in the automotive case it was the short term interests of a number of the region's larger companies that prevailed - in particular MG-Rover. AWM's frustration resulted in them by-passing the Accelerate Management Board, then chaired by the MD of MG-Rover, and providing the major funding at Warwick Manufacturing Group described above.

However, some progress towards addressing the longer term needs was made. For example, considerable resources were made available to retrain workers, but mainly up to level 2 (GSCE equivalent) skills. Whilst this was a good start, future manufacturing, and the new growth industries, will require level 3 or 4 skills. In other words, the UK needs to go further and faster to compete in high-value added activities in a globalising economy.

\section{Concluding Comments}

Whilst the MG-Rover collapse was a substantial shock to the west Midlands economy, the impact would have been much greater if the firm had collapsed in 2000 . The five years of continued production over 2000-2005 allowed many suppliers to adjust and diversify away from MG-Rover, aided by the work of the first RTF. This was a very real 'success' for local policy makers. The response after the collapse was also a major effort that minimised job losses. Challenges remain, however, especially for the least well-skilled workers as the manufacturing base hollows-out locally, with high levels of local unemployment and a low-skills base in much of the Birmingham economy.

The MG-Rover case raises a number of critical issues. Firstly, the coordination of regionally based 'cluster' policies where the 'cluster' in question crosses administrative regional boundaries, calls for a more coordinated approach to join up regionally based policies. Work by AWM at the regional level would be more effective in building local competencies if the fragmentation of regional level policy delivery was properly addressed. Secondly it is clear that in common with other RDAs the Agency lacked resources for economic development. In the West Midlands case the retention in 2000 of $£ 129$ million of RSA assistance within the region that 
had been earmarked for BMW plus another $£ 176$ million in 2005 to pick up the pieces after the collapse was an implicit recognition that AWM had neither sufficient staff or financial resources the to tackle a problem of this scale. It therefore needed to rely pre-existing structures and funding mechanisms and was therefore only able to address the short term issues. In doing so it was constrained by the limitations of preexisting policies as mechanisms to tackle the longer term needs of the region to invest in higher level skills and technology.

Even today, some eight years after the initial Rover crisis, RDAs in general have limited flexibility in utilising the resources available to them, being heavily constrained by pre-ordained silos of funding from central government. Although funding is now in the form of a block grant or 'single pot', with the ability to vire across budgets, central government has set very specific targets for RDAs to meet, which considerably limit their room for manoeuvre (Fuller et al, 2002). The paradox thus arises that RDAs are overly constrained in terms of their ability to pursue strategic objectives in terms of regional industrial policy, but that their efforts to foster the development of local 'clusters' or sectors are insufficiently coordinated on a national or inter-regional basis.

Whilst AWM and the RTF have genuinely attempted to improve regional economic prospects by attempting to diversify, modernise and regenerate those areas most affected by the shake-out in the auto industry and through building regional competencies and social capital, there remains the key question of who is "joining it all up" properly at the regional, inter-regional and national level and how to take a strategic and long term view of economic development policy against a background of short term imperatives.

\section{References}

Accelerate. (2002) www.accelerate.co.uk

Andersson, T., Serger, S., Sörvik, J. and Hansson, E. (2004) The Cluster Policies Whitebook, IKED, Mälmo, Sweden 
Andriani, P, C Jones C, M Perkmann, De Propris, L. Sena, V. R Delbridge, K. Möslein and Nelly, A. (2005). Challenging Clusters. The Prospects and Pitfalls of Clustering for Innovation and Economic Development. London: AIM Research.

Armstrong, K (2006) Life after MG Rover: A Report prepared for BBC Radio 4. London: The Work Foundation.

Armstrong, K, Bailey, D, De Ruyter, A, Mahdon, H, and Thomas, H. (2008). 'The Impact of Plant Closures on Workers: a Comparison of MG Rover in the UK and Mitsubishi in Australia', Policy Studies, 29 (3).

Asheim, B Cooke P, Martin R (2006) Clusters and Regional development: Critical Reflections and Explorations. Routledge, London.

AWM (1999) Creating Advantage. The West Midlands Economic Strategy. Advantage West Midlands, Birmingham

AWM (2001) Agenda for Action Spring 2001. Advantage West Midlands, Birmingham

Ayers, S., Mawson, J. and Pearce, G. (2002) Institutional collaboration in the West Midlands region. In J. Tomaney and J. Mawson (eds.) England: The State of the Regions. Policy Press, Bristol

Bailey, D. (2003) Globalisation, Regions and Cluster Policies: The Case of the Rover Task Force, Policy Studies, 2003, Vol.24, No.2/3.

Bailey, D. (2003a) Does the EU Need a Transnationals Policy? The BMW-Rover Affair as a Case of Corporate, Strategic and Government Failure. Birmingham Business School Working Paper, 2003-11.

Bailey, D Kobayashi, S and MacNeill, S (2008) Rover and Out? Globalisation, the West Midlands Auto Cluster, and the end of MG-Rover, Policy Studies, Vol. 29, Iss.3.

Benneworth, P. (2001) Regional Development Agencies: The Early Years. Seaford: Regional Studies Association.

Benneworth, P and Henry, N (2004) Where is the Value Added in the Cluster Approach? Hermeneutic Theorising, Economic Geography and Clusters as a Multiperspectival Approach. Urban Studies, 41, 5/6 pp. 1011-1023

The Birmingham Post. 2006. Aerospace creates three times as many Jobs as Automotive. 20/04/06.

The Birmingham Post. 2006. Could DTI have stopped this becoming this? 14/03/06.

The Birmingham Post. 2008. Longbridge News is a Step in the Right Direction. 10/05/08.

Birmingham Mail (2005). The Real Cost of Rover's Collapse. 21/09/05. 
BSEDF (Birmingham and Solihull Economic Development Forum). 2005. Economic Review 2005/6. Birmingham: Birmingham and Solihull Economic Development Forum

Burfitt, A and E Ferrari. (2008) The Housing and Neighbourhood Impacts of Knowledge-Based Economic Development following Industrial Closure, Policy Studies, Vol.29, Iss.3.

Burfitt A, MacNeill S, Gibney, J (2007) 'The Dilemmas Of Operationalising Cluster Policy: The Medical Technology Cluster In The West Midlands', European Planning Studies 15.9, 1273-1290

Camagni, R. (1991) Local 'Milieu', Uncertainty and Innovation Networks: towards a New Dynamic Theory of Economic Space, in R Camagni (ed) Innovation Networks: Spatial Perspectives. London: Belhaven.

Cowling, M and N Isles (2005) Sent to Coventry? The Re-Employment of the Longbridge 5000. London: The Work Foundation.

Department of Trade and Industry (1998): Our Competitive Future: Building the Knowledge Driven Economy. White Paper, TSO. London.

Department of Trade and Industry (2003) Criteria for Success in Cluster Development, Report by ECOTEC Consulting Ltd., DTI, London

Department of Trade and Industry and Department for Education and Science (2001). Opportunity for All in a World of Change. White Paper on Enterprise, Skills and Innovation, TSO, London

De Propris, L. (2000) Innovation and Inter-Firm Cooperation: the Case of the West Midlands, Economics of Innovation and New Technology, Vol.9.

Enright, M.J. (2001) Regional clusters: what we know and what we should know. Paper presented at the Kiel Institute International Workshop on Innovation clusters and interregional Competition, November 2001.

Fuller, C, R J Bennett and M Ramsden. (2002) The Economic Development Role of English RDAs: The Need for Greater Discretionary Power, Regional Studies, Vol 36, No 4.

Gough, J. (2003) The Genesis and Tensions of the English Regional Development Agencies. European Urban and Regional Studies, 10(1), pp. 23-38

Holweg and Oliver (2005) Who Killed MG Rover? Cambridge: The Cambridge-MIT Institute.

House of Commons (2004) Support to Businesses from regional development agencies. Fifth Report of Session 2003-04, Trade and Industry Committee, TSO, London 
House of Commons (2006) The Committee of Public Accounts. The Closure of $M G$ Rover. Report, Together with Formal Minutes, Oral and Written Evidence. HC10013. London: The Stationery Office Ltd.

House of Commons. Trade and Industry Committee (2007). Success and Failure in the UK Car Manufacturing Industry. Fourth Report of Session 2006-07. Report together with formal minutes, oral and written evidence. HC399. London: The Stationery Office. March 2007.

Hussain, M. (2007) Is UK Innovation on Track? New Statesman, 05/03/2007; 28-29.

Hutton, W. (1999) 'Why Rover was driven out of UK Hands' in The Stakeholder Society. Writings in Politics and Economics. Oxford: Polity Press. Pp.58-60.

Hutton, W. (2007) Manufacturing is still Critically Important, New Statesman, 05/03/2007; 4-6.

Keeble, D, C Lawson, B Moore and F Wilkinson. (1999) Collective Learning Processes, Networking and 'Institutional Thickness' in the Cambridge Region, Regional Studies, Vol 33, No 4.

Leitch, S (2005) Skills in the UK: The Long Term Challenge. The Stationery Office, London.

Lundequist, P and Power D. (2002) Putting Porter into Practice? Practices of Regional Cluster Building: Evidence from Sweden, European Planning Studies, Vol.10, No.6.

MacNeill, S (2003) The West Midlands Automotive Cluster. Report for the European Monitoring Centre for Change (EMCC).Available at http://www.eurofound.europa.eu/emcc/publications/2004/ef0493en2.pdf

MacNeill, S. Srbljanin, A. and Bentley, G (2001) Rover Task Force Supply Chain Support Phase 1: Evaluation. Report for Birmingham Chamber of Industry and Commerce, University of Birmingham

Malecki, E J. (1997) Technology and Economic Development: The Dynamics of Local, Regional and National Competitiveness. Longman.

Martin, R. and Sunley, P. (2003) Deconstructing clusters: Chaotic concept or policy panacea? Journal of Economic Geography, 3, pp. 5-35

Mawson, J (2000) In G Bentley and J Gibney, ed.s, Regional Development Agencies and Business Change. Aldershot: Ashgate.

National Audit Office. 2006. The Collapse of MG Rover. HC961 Session 2005-6. London: The Stationery Office.

Office of National Statistics (2007) Annual Business Inquiry. 
Owen, G (1999). From Empire to Europe. The Decline and Revival of British industry Since the Second World War. London: Harper Collins.

Oughton, C, De Propris, L, MacNeill, S (1996). The West Midlands Regional Innovation Strategy. Advantage West Midlands, Birmingham.

Peck, F and McGuinness, D. (2003) Regional development agencies and cluster strategies: Engaging the knowledge-base in the North of England, Local Economy, 18(1), pp. 49-62.

Raines, P. (Ed.) (2002) Cluster Development and Policy, Ashgate, Burlington VT

Roberts, P. and Benneworth, P. (2001) Pathways to the future? An initial assessment of RDA strategies and their contribution to integrated regional development. Local Economy, 16(2), pp.142-159

Rover Task Force (RTF1). (2000) Final Report and Recommendations to the Secretary of State for Trade and Industry. Birmingham: Advantage West Midlands.

Rover Task Force (RTF2). (2006) Final Update Report: The Work Goes On. Birmingham: Advantage West Midlands.

Rowthorn, R and K Coutts. (2004) Deindustrialisation and the Balance of Payments in Advanced Economies, Cambridge Journal of Economics, 28(5), 767-790.

Sadler, D. (2004) Cluster evolution, the transformation of old industrial regions and the steel industry supply chain in North-east England. Regional Studies, 38(1), pp. 5566

Steiner M. (2006) Do Clusters 'Think'? An Institutionalist Perspective on Knowledge Creation and Diffusion in Clusters, in B Asheim, P Cooke and R Martin (eds) Clusters and Regional Development: Critical Reflections and Explorations. Routledge, London

Storper, M. (1997) The Regional World: Territorial Development in a Global Economy. New York: Guilford.

Tilson, B. (1997) Survey of Firms in the Automotive Components Sector in the West Midlands Region. Final Report for the West Midlands Development Agency. Birmingham: Centre for Urban and Regional Studies, The University of Birmingham.

Tully, J and N Berkeley. (2004) Visualising the Operating Behaviour of SMEs in Sector and Cluster: Evidence form the West Midlands, Local Economy, Vol.19, No.1.

Waters, R and H Lawton Smith. (2002) Regional Development Agencies and Local Economic Development: Scale and Competitiveness in High-technology Oxfordshire and Cambridgeshire, European Planning Studies, Vol 10, No 5.

Webb, D. and Collis, C. (2000) Regional development agencies and the "new regionalism' in England. Regional Studies, 34(9), pp. 857-864 
${ }^{1}$ Birmingham Business School, UK. The authors wish to acknowledge the support of the ESRC under award number RES-000-22-2478. contact: d.g.bailey@bham.ac.uk

${ }^{2}$ An Act of Parliament established the English RDAs in 1998. The RDA for London was launched in 2000 when the Greater London Authority was set up.

${ }^{3}$ The consortium comprised four former directors of the company who were able to buy all the assets, subsidiary companies and the Rover brand for a symbolic $£ 10$.

${ }_{5}^{4}$ Interview with Gerry O’Donnell at GOWM, 09/03/01.

${ }^{5}$ The company was formed as part of the formed by the privatisation of a former Government Defence Research Establishment

6 These brands were all part of the Ford Premium Automotive Group (PAG). However, Ford's significant losses worldwide, forced the sale of all three companies. Aston Martin was sold to a consortium of local business men while Jaguar-Land Rover has been bought by the Indian conglomerate, TATA.

${ }^{7}$ PARD stood for Premier Automotive Research and Development and was set up at a time when Ford had brought its luxury brands (Volvo, Lincoln, Jaguar, Land Rover and Aston Martin) under a single organisation. The company was broken into separate parts in 2002 following concerns about the effect on Ford's 'home' luxury brand, Lincoln.

${ }^{8}$ Ford reported a worldwide loss of $\$ 12$ billion in 2006.

${ }^{9}$ In 1952 under central government pressure the Birmingham based Austin company merged with Morris based in Oxford to form the British Motor Corporation. The objective was to create a 'national champion' to rival Ford, FIAT, Volkswagen etc.

10 Beyond February 2006, virtually nothing is known about the remaining workers still unemployed, the long term impact of those on long term benefit, and in particular the impact of the MG Rover closure on the wider community and stakeholders in the region (see the latest report from the House of Commons (2007), which notes the differences in estimates of employment rates of former MG Rover workers and the lack of information on the wider impacts of the closure).

${ }^{11}$ At the time of its final sale, the Longbridge site, assembly facilities, and rights to manufacture the MG brand, were sold to Nanjing Automotive Corporation (NAC). However, the main part of the IPR and the rights to build Rover cars were sold separately to the Shanghai Automotive Industry Corp (SAIC). At that time MG-Rover directors had hoped cooperation with SAIC would lead to joint ventures or even a take-over by the Chinese firm. However, in a 'final' twist with a strong steer from the Chinese Government, SAIC and Nanjing announced, in December 2007, a deal to combine their assets, with SAIC as the dominant partner. The company has indicated that they see Longbridge as a platform for entering the European market. The remainder of the site is planned as a high technology business park plus retail and educational facilities and housing under the Longbridge Area Action Plan. The development is forecast to bring over 10,000 new jobs to the area. 